\title{
Propranolol for the Treatment of Hemangiomatosis with Hepatic Lesions: Case Report with Great Response
}

\author{
Bruna Moretto ${ }^{1}$, Mariana Costa Garcia' ${ }^{1}$, Roberto Moreira Amorim Filho ${ }^{2}$ and Gustavo Moreira Amorim ${ }^{1,2 *}$ \\ ${ }^{1}$ Faculty of Medicine of South Santa Catarina University, Brazil \\ ${ }^{2}$ Santa Tereza Sanitary Dermatology Hospital / Santa Catarina Health Secretary, Brazil
}

Submission: February 04, 2020; Published: February 14, 2020

*Corresponding author: Gustavo Moreira Amorim. Dermatologist from Federal University of Rio de Janeiro. Master's Degree in Anatomical Pathology from Federal University of Rio de Janeiro. Dermatology Professor from Faculty of Medicina of South Santa Catarina Universisty. Dermatology from Santa Tereza Sanitary Dermatology Hospital da Faculdade de Medicina da Universidade do Sul de Santa Catarina. Médico Dermatologista, Brazil

Abstract

We present a case of a 2 months-old male nursling with neonatal hemangiomatosis with skin and hepatic, showing great response with systemic propranolol, with good acceptance, without side effects, after a 9 months follow-up.

Keywords: Hemangiomatosis, Disseminated; Hemangioma/drug therapy; Liver Neoplasms/drug therapy; Propranolol/therapeutic use

Keywords: IH: Infantile Hemangioma; ISSVA: International Society for the Study of Vascular Anomalies; NH: Neonatal Hemangiomatosis; BNH: Benign Neonatal Hemangiomatosis; VEGF: Vascular Growth Endothelial Factor; DNH: Diffuse Neonatal Hemangiomathosis; FGF: Fibroblast Growth Factor

\section{Introduction}

Vascular tumors are vasculature neoplasms that present endothelial cell proliferation. Infantile hemangioma (IH) is a proliferation of endothelial cells, that develop during the first 12-18 months of life, and then involute1. The lesions may be present at birth as a precursor lesion, but practically all lesions are noticeable at the end of the first month of life [1]. Based on the latest classification by the International Society for the Study of Vascular Anomalies (ISSVA), IH are classified (according to its pattern) as local, multifocal, segmental or indeterminate [2]. The term "neonatal hemangiomatosis ( $\mathrm{NH}$ ) is used to describe the condition of multiple HI (multifocal pattern) and it is cathegorized as "benign neonatal hemangiomatosis" (BNH) and "diffuse neonatal hemangiomathosis"(DNH) [3].

BNH stands for multiple cutaneous hemangiomas without the involvement of internal organs [3]. Its growth phase occurs in the first weeks of life, later passing to the stationary phase and, finally, involution [4]. HND is defined by the identification of hemangiomas in 3 or more organ systems, it must be observed in the neonatal period, in addition to there being no evidence of malignancy [3]. Its development probably begins in the intrauterine phase and progresses along with the fetus growth. The current trend is to adopt a spectral concept and the use of the terms HN with and without visceral involvement [1].

\section{Case Report}

Two month old male nursling, born by cesarean section with 39 weeks and 6 days of gestational age, uneventful, exclusive breastfeeding up to 2 months, later supplemented with milk formula, showing adequate weight-stature gain and neuropsychomotor development, immunizations according to schedule; comes in consultation due to reddish skin lesions, which appeared in the first month of life. Upon examination, multiple erythematousviolaceous, fibroelastic nodules, reducible to digital pressure, measuring between 0.2 and a maximum of $1.5 \mathrm{~cm}$, with diffuse distribution throughout the entire integument. None of them ulcerated or with phlogosis. Apparently painless on palpation. 
With the clinical diagnosis of neonatal Hemangiomatosis, ultrasound (USG) transfontanellar and total abdomen was requested, in addition to a referral to the pediatric Cardiologist for evaluation for the use of oral propranolol. Normal cardiological examination and electrocardiogram, authorizing systemic treatment. Central nervous system USG was normal, meanwhile abdominal image showed two nodules of up to $1.0 \mathrm{~cm}$ in the liver parenchyma, suggestive of hemangiomas. Treatment with manipulated Propranolol, 10mg / $\mathrm{ml}$ in suspension, at a dose of
$2 \mathrm{mg} / \mathrm{kg} /$ day, was started at 3 months and 5 days of age, divided into two doses, after the morning and late afternoon feedings.

Comparative photographs record the evolution of the lesions in the pre-treatment period and after 9 months (Figure 1). The patient presented involution of all skin lesions, mostly maintaining residual hyperchromia. There were no side effects related to medication. Abdominal control USG with the same radiologist considered as normal (therefore it is not possible to identify the lesions previously seen, after 6 months of medication).
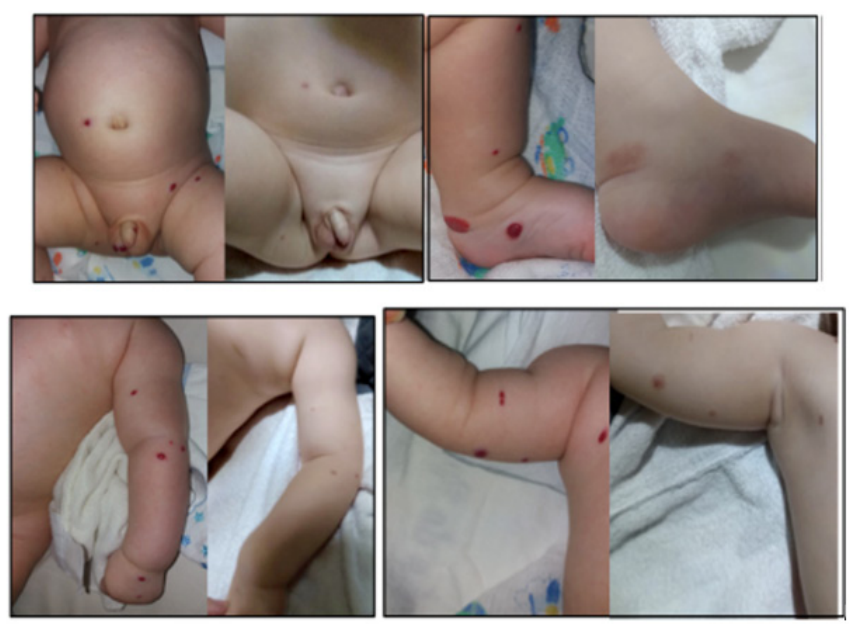

Figure 1: Comparative photographs record the evolution of the lesions in the pre-treatment period and after 9 months.

\section{Discussion}

The natural history of hemangiomas is divided into 3 phases. The first phase, also called a precursor lesion, appears in the first days of life (most of which is very evident at the end of the first month of life) and can present as an anemic, erythematous and/or ecchyotic spot, grouping of red-live or telangiectasias surrounded or not by an anemic halo. The rapid growth of this phase is usually greater in the first 3 to 6 months of life, but can reach up to one year of age $[5,6]$. The second phase is the involutive one, which is characterized by a regression of approximately $10 \%$ of the injury per year. Ultimately, the last phase is the one that represents the involuted injury. It is expected that in approximately half of the patients it will be complete and in the other half it will present some type of residual lesion [5,6]. As it is more rare, HN does not have a well-defined natural history. Forms restricted to the skin have a good prognosis. However, it is difficult to establish who are the patients who evolved with complete bleaching of the lesions $[3,7,8]$.

The diagnosis is clinical, and can be supported by histopathological examination when dubious or even to support indication of systemic treatment $[1,5,6]$. In the present case, we consider the clinical aspect and classic evolution sufficient, taking into account the cost/benefit of performing biopsy in an infant patient. The treatment of $\mathrm{HN}$, especially with lesions restricted to the skin, can be expectant, individualizing according to the number and topography of the lesions $[3,4,7,8]$. In the present case, considering the number of lesions, the potential esthetic impairment if there was no involution, in addition to liver injury, systemic treatment was chosen.

Propranolol is the first-line treatment of $\mathrm{HI}$, especially in complicated, segmental or unfavorable lesions $[1,5,6]$. It is used at a dose of $2-3 \mathrm{mg} / \mathrm{kg}$ / day, divided into two or three doses, via oral. It is effective in the first two phases of the disease as it stimulates vasoconstriction of capillaries, decreases the angiogenesis of endothelial cells, by reducing the expression of vascular growth endothelial factor (VEGF) and fibroblast growth factor (FGFb) genes, in addition to inducing apoptosis of endothelial cells6. The experience of its use in $\mathrm{NH}$ is small, still restricted to small reports published in the literature, being off-label. However, it finds support in its logic of use and disease mechanism, taking advantage of publications involving its use of $\mathrm{HI}[7,8]$.

\section{Conclusion}

We present an illustrative case of HN with skin lesions and liver damage, treated with Propranolol orally, with good acceptance, without side effects, in addition to a positive outcome in follow-up after 9 months of continuous use.

\section{References}

1. Purin KSM, Pereti MC, Fillus-Neto J, Olandoski M (2017) Chromoblastomycosis: Tissue modifications during itraconazole treatment. An Bras Dermatol 92(4): 478-483. 
2. Brito AC De, Jesus M De, Bittencourt S (2018) Chromoblastomycosis: etiological, epidemiological, clinical, diagnostic and therapeutic update. An Bras Dermatol 93(4): 495-506.

3. Sali AP, Sahay A (2017) Chromoblastomycosis of the leg. Pol J Pathol 68(2): 182-184.

4. Queiroz Telles F (2015) Chromoblastomycosis: A neglected tropical disease. Rev Inst Med Trop Sao Paulo 57(1): 46-50.

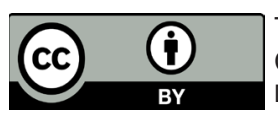

This work is licensed under Creative Commons Attribution 4.0 License DOI: 10.19080/JOJDC.2020.02.555586
5. Queiróz AJR, Pereira Domingos F, Antônio JR (2018) Chromoblastomycosis: clinical experience and review of literature. Int J Dermatol 57(11): 1351-1355.

6. Queiroz Telles F, De Hoog S, Santos DW, Salgado CG, Vicente VA, et al. (2017) Chromoblastomycosis. Clinical Microbiol Rev 30(1): 233-276.

\section{Your next submission with Juniper Publishers will reach you the below assets}

- Quality Editorial service

- Swift Peer Review

- Reprints availability

- E-prints Service

- Manuscript Podcast for convenient understanding

- Global attainment for your research

- Manuscript accessibility in different formats

( Pdf, E-pub, Full Text, Audio)

- Unceasing customer service

Track the below URL for one-step submission

https://juniperpublishers.com/online-submission.php 